\title{
Initial Insomnia
}

National Cancer Institute

\section{Source}

National Cancer Institute. Initial Insomnia. NCI Thesaurus. Code C35581.

Difficulty falling asleep. 